\title{
The 50th Year of Green Revolution - Why This Cataclysmic Turn after 1995?
}

\author{
J Cyril Kanmony* \\ Department of Economics, PG and Research Centre, Scott Christian College, Nagercoil, India
}

\begin{abstract}
In India a pilot scheme called Intensive Agricultural District Programme (IADP) was introduced in seven districts in 1960-'61. However, the modern agricultural technology called High Yielding Varieties Programme (HYVP) or simply Green Revolution was introduced throughout the country in 1967-68. The introduction of HYVP transformed the 'ship-to-mouth' Indian economy into a 'ship-to-others' economy. The production of agricultural products, cereals in particular, increased tremendously after the introduction of HYVP. The total cereals production increased to 162 million tonnes in 1990-'91 from a mere quantity of 62 million tonnes in 1960-' 61 . It further increased to more than 235 million tonnes in 2015-' 16 . As cereals production increased the total food production also increased; it increased from 82 million tonnes in 1960-' 61 to 176 million tonnes in 1990-'91 and to more than 252 million tonnes in 2015-'16. Of the cereals, wheat experienced a large quantum of increase; it was only 10 million tonnes in 1960-61, but in 1970 it had doubled and in 2013-'14 the production was 95.8 million tonnes. The ratio of wheat production to rice production was only 31 in 1960-'61, but it increased to 74 in $1990-' 91$ and further to 85 in the 2000s and the yield per hectare of wheat has also increased from $850 \mathrm{~kg}$ to more than $2900 \mathrm{~kg}$ in the same period (Datt and Sundaram; Mahapatra). However, the growth of agriculture is only $1 \%$ between 1991 and 2016 , while other sectors grow at $8 \%$ per annum.
\end{abstract}

Keywords: Revolution; Agricultural; Economy; Production

\section{Introduction}

Green revolution aimed at not only increasing agricultural production but also wiping out the sufferings of the poor Indian farmers [1]. Production increased considerably but the condition of Indian farmers is getting worse. The proverb in Tamil, "uzhavan kanakku parthal uzhakkum minchathu" (if farmers calculate then there is no net income, Uzhakku is about one sixth of a $\mathrm{kg}$ ) is very true. Everything was okay as crop was good and prices were almost favourable up to the middle of the 1990s. After the signing of GATT by India in 1995, the Indian agriculture has taken a cataclysmic turn for the worst [2] and it still continues and it appears that there is no end to the woes of Indian farmers unless there is a wonder. The farm lands are becoming killing fields of farmers as farming is a loss-making enterprise like the Air India and the current agrarian crisis is like a multiple organ failure in humans. The situation in the handloom sector is recurring in the agricultural sector as youngsters are not ready to take up their family occupation.

\section{Literature Review}

Our farmers are betrayed by politicians, ignored by bureaucrats, exploited by intermediaries, shunned by the elite and often cheated by nature. They are placed at the brink of being ruined under the new economic development model. Without any solution to their woes, they are now in protest demanding for either a remunerative price or the waiving of farm loans. For example, in Karnataka in August 2016 and in June 2017, in Chhattisgarh in December 2016, in Punjab in January 2017, in Odisha in March 2017, in Uttar Pradesh in April 2017, in Andhra Pradesh, Maharashtra, Haryana, West Bengal and Telengana in May 2017 and in Madhya Pradesh, Rajasthan and Tamil Nadu in June 2017 farmers are in protest. In some areas, farmers are in upheaval due to the taking away or the proposal of taking away of their fertile lands by the government or government approved agents for non-farm purposes. For example, farmers have protested in Bhandar and Singur, West Bengal and in Neduvasal and Kadiramangalam, Tamil Nadu. In the recent past not, a single day has passed without farmers' protest (Mahapatra). At a top of all these, in Madhya Pradesh in the June 2017 protest, six farmers were shot down by the police [3].
Why did our agriculture take such a downside? Farmers' life is adversely affected by many things such as excess rainfall, drought, hailstorms, temperature rise, price crash, rising input cost, subsidy cuts and non-availability of labourers, fertilisers and manures for their fields and markets for their produce. Farmers experienced very often crop failure; sometimes crops are wilted due to monsoon failure and other times they are damaged by excess rainfall. Yields and prices are unpredictable; many times, prices crash. At the same time the price of inputs like seed and fertilizers is on the increase very much. Hence the net revenue is negative or meagre. All these result in utter poverty of farming families, malnutrition of their members, loan default, migration, suicides and quitting of farmers from agriculture. The main reasons for the farming crisis are: non-remunerative price, rising cost of production, unpredictable climate and yield and lack of government support and farsighted policies.

\section{Non-remunerative Price}

Poor crop or bumper crop farmers are at the receiving end. Agriculture is the exact field where the Cobb-Webb theorem is well applied. If price is low output will fall and price will rise in the next season and if price is high output will increase in the next season and in turn it forces price to come down. Almost all crops experience unnecessary price volatility. The prices of agricultural produce fluctuate even within a day. They are determined by commission agents or wholesale traders who fix a low price when a large quantity arrives in the market to earn an abnormal profit. The pricing policies of governments also play a key

*Corresponding author: J. Cyril Kanmony, Department of Economics, PG and Research Centre, Scott Christian College, Nagercoil 629001, India, Tel: + 919943869198, E-mail: cyrilkanmony@ymail.com

Received September 12, 2017; Accepted September 25, 2017; Published September 29, 2017

Citation: Kanmony JC (2017) The 50th Year of Green Revolution- Why This Cataclysmic Turn after 1995? Review Pub Administration Manag 5: 224 doi:10.4172/2315-7844.1000224

Copyright: () 2017 Kanmony JC. This is an open-access article distributed under the terms of the Creative Commons Attribution License, which permits unrestricted use, distribution, and reproduction in any medium, provided the original author and source are credited. 
role; due to wrong exam policies the price of many products crash. For example, in June 2016, tur dal (pigeon pea) was priced at Rs.10,00012,000 per quintal and so farmers in Maharashtra were advised to cultivate tur dal. But the central government allowed import of it in September 2016 and so the imported dal flooded the market and the price crashed even below the MSP; the market price was Rs4,000/- but MSP was Rs.5,050.

It is the reality in Madhya Pradesh, where prices of products like pulses, oilseeds potato, onion, garlic and green peas crashed very much due to a bumper harvest after seven consecutive crop failures; the price of onion was only 25 paisa per $\mathrm{kg}$ at Ratlam mandi (market) and at Indore mandi the price of green peas crashed by $80 \%$, potato and garlic by $60 \%$, tomato by $40 \%$ and onion by $25 \%$ at the beginning of June 2017. It is the case of orange and chilli too -the price of orange fell by $38 \%$ and chilli by $55 \%$. The green peas' price went down to Rs.2. No one was ready to purchase even at that rate [4]. In Andhra Pradesh, the main chilli producing centre, chilly prices crashed very much due to bumper crop. In Tamil Nadu, at the end of 2016 and early 2017 carrot was sold for Rs.10, cauliflower for Rs. 15 and tomato for Rs.5 per kg. In producing centres, the prices were very low. For example, in Thenkasi area (a production centre of tomato and other products such as onion), the price of one kg of tomato was only Rs2/- and in Pollachi area (producing centre of cabbage etc.), the price of a $\mathrm{kg}$ of cabbage was only Rs. 2 and a $\mathrm{kg}$ of cauliflower was Rs.7 and a kg of carrot was only Rs.4 [5]. Hence a lot of agricultural products like tomato were dumped by the roadside as taking back them home involved a huge transportation cost and there was also no space in their houses to store them. This is the realty in almost all areas and in all years. In Krishnagiri in 2013, a crate (24 kg) of tomatoes was sold at Rs.20 [6].

For many agricultural products, the price that prevails in the market is the same price at which they sold their produce 20 years ago and many times even lesser than that. For example, prices of agricultural products declined by $60 \%$ to $70 \%$ in comparison with the prices of agricultural raw materials between 1980 and 2003. In West Bengal, what rice farmers earned in 2002-2003 is $28 \%$ less than what they earned in 19961997. The income of sugarcane farmers decreased in Uttar Pradesh by $32 \%$ and in Maharashtra by $40 \%$ during the same period. The price of cotton in 2003 was only $33 \%$ of the 1980 price and for coffee it was only $17 \%$ [7]. On the other hand, the prices of input increase sharply. Indian farmers do not demand for a luxurious life but for only good seeds and fertilizers, uninterrupted power supply, flexible loan from government institutions, protection from middlemen and reasonable prices for their products, but all these are not available to them.

As their net income is very low/nil the farmers lead a hand-tomouth life. As per the NSSO report a farmer can earn only Rs. 4000 but an unskilled labourer can earn at least Rs.6600 per month. Many studies reports that a good farmer can earn only Rs. 1700 to 2000 from an acre in a month and others can earn only less than that [8]. The Economic Survey 2016-'17 puts it at Rs.1600 and the NITI Aayog reports that $53 \%$ of Indian farmers are below the poverty line, i.e., an income of less than Rs.900 [4]. While the per capita income of the general population at current prices increased from Rs.254 in 1950-'51 to Rs.1,03,219 in 2016-'17, most of our farmers are still under debt of a few lakhs. As per the NSSO Survey 2012-'13, the percentage of households with outstanding loan is estimated at $51.90 \%$ and the average amount of outstanding loan per agricultural household is Rs.47,000 [8]. The percentage of households in debt was only 26 in 1991 [9]. The per farmer debt at constant prices increased from Rs.1254 to Rs.3884 between these two periods, showing an increase of $210 \%$ within a period of 12 years. The recent ban on selling livestock for meat makes farmers still poorer [10]. The losses of income due to non-remunerative prices and demonetisation have left farmers with limited/no working capital to invest in the next crop. They have one source of income but multiple sources of debt/loan. During every crop season the farmers borrow heavily and put themselves in another web of debt. Thus, Indian farmers are unable to come out of the vicious circle of poverty.

\section{Minimum Support Price (MSP)}

The next reason is the fixation of a very low support price and a limited coverage of farm products by the support price. The central government has declared MSP for only 24 crops, but procures at that rate only two crops - wheat and rice, and leaves other crops to market forces to be volatile. It is authenticated by the report of the NSSO [11] that only $6 \%$ of Indian farmers mostly from Punjab and Haryana, the major grain producing states sell their crops at MSP. The Commission for Agricultural Costs and Prices reported that farmers have not earned any profit from most of the food- and non-food crops since the mid 1990 's as the MSP fails to cover even the cost of production $[11,12]$. Even the governments are not ready to purchase all the products at the MSP. In Madhya Pradesh, the state government procured only one third of the wheat produced in 2013-'14. Farmers have no alternative other than to sell them at the market price, which is very often below the MSP. There is no use in fixing MSP without procurement guarantee to purchase all the goods produced by farmers. India needs around 50,000 regulated mandis to provide price discovery facility to all farmers, but it has only around 7,200 and of these nearly $80 \%$ do not have facilities such as mechanical graders and sieves to grade agricultural products [11].

MSP itself fails to take into account the ever-rising input cost and other charges as well as the variation in labour cost and input cost at different places. For example, the labour charges in northern and central India range from Rs.70 to 100 a day but in the southern districts of Tamil Nadu India it is Rs.400 for four hours and Rs.600 for a day. M.S. Swaminathan Committee recommended for a minimum support price covering 1.5 times the cost of production, which is in the shelf for the last eleven years. Producing any agricultural produce is easier than selling it. Every farmer tries to sell his produce immediately after the harvest like disposing of a dead body as there is lack of facility to store them.

\section{Government Policies}

It is the duty of the government to take suitable import and export policies in order to safeguard both farmers and consumers. The government however allows free import even at the times of bumper crop and reduces export duty at the time of fewer crops, which boosts export. Briefly speaking India is changing its policy of self-sufficiency in food production. Between 2014 and 2017 the import of cereals such as wheat, maize and rice increased by 110 times. India's annual food import bill is more than Rs.1.4 lakh crore and to compensate the rising import bill the government tries to cut fund for other agriculture-related schemes like irrigation and power $[8,13]$. Though the government expected an output of 4.23 million tonnes of tur dal this year from 2.56 million tonnes in 2015-' 16 , there was $24 \%$ increase in tur dal import this year, from 462,710 tonnes in 2015-'16 [14]. The agrarian import in 2008-2009 was only $2.09 \%$ of India's total imports. It increased to $4.43 \%$ in 2014 -' 15 and to $5.63 \%$ by $2015-2016$. In 1993 -' 94 only $3 \%$ of the edible oil consumed was imported but today it is $70 \%$, but Jitendra [11] and Goswami, [15] estimate it at 75\%. The government reduced the import duty on palm oil by $5 \%$ and so the domestic market is flooded with cheap imported palm and soybean oil though in 2015-'16 India 
had a bumper crop of oilseeds. As a result, peanuts and soybean are sold below the MSP. The price of coconut has also crashed very much. India not only imports wheat, rice and oil but also pulses; $25 \%$ of its pulses is imported, spending around Rs.25,600 crore in 2016-'17 [13].

\section{Monsoon Failure/Ecological Factors}

Environmental factors such as falling rainfall, rising temperature, and other ecological factors such as gale and storm also play a very important role in creating farming crisis. Sometimes excessive rainfall, some other times drought and very often gale become the cause for great damage to crops. Due to severe drought thousands of acres of crops and thousands of coconut palms were withered away in southern India, particularly in Tamil Nadu. Tamil Nadu is experiencing the worst drought in 140 years. In 2012 also, Tamil Nadu experienced severe drought- in Virudhunagar district of Tamil Nadu 71,283 hectares covered by various crops were affected and wilted away and crops on 70,837 hectares suffered a loss of $50 \%$ or more and in Madurai district the respective figures are 61,589 and 29,051. In Dindigul district, the area affected by non-availability of water or drought is 2.73 lakh hectares. Farm activities did not take place in another 1.78 lakh hectares. In Sivaganga district, out of 1.19 lakh hectares of paddy cultivated, 1.05 lakh hectares of paddy were hit by drought and suffered more than $50 \%$ loss [16]. The area under cultivation, production and productivity of rice in the Cauvery delta region in 2004 - $^{\prime} 05$ was about $50 \%$ less than what it was during the normal period due to the occurrence of droughts and floods alternatively [17]. The same was the condition in most districts and other states, but no government is bothered about the distress of farmers.

Sudden and unexpected rain also affects the livelihood of farmers. For example, Natarajan et al. [17] bring to light that the sudden and unexpected rainfall in the state of Karnataka in October 2009 damaged the soil, crops, and infrastructure [18]. The highest excess rainfall was 924\% more than the normal level. It was estimated that, flood water washed away 287 million tonnes of top fertile soil, 8.17 lakh tonnes of soil nutrient, 8 lakh tonnes of organic matter from the red soil and 30 lakh tonnes of organic matter from the black soil. The total soil nutrient loss was estimated at Rs.6250 million. The total cost required to bring back the soil to the original level was calculated as Rs.8530 million. Mandal [19] observes that in Assam, where rice is the dominant crop, every year flood damages a large area under crops. The damages are very high during the winter season. Flood destroyed the standing crops, resulted in water-logging, eroded fertile soil and adversely affected the area under crops and production. Just three days of heavy downpour at the end of 2009 in Karnataka and Andhra Pradesh resulted in millions of acres of crops being damaged [20]. The same situation prevails at present in North India, in at least five states namely: Assam, Bihar, Gujarat, Rajasthan and West Bengal in particular. Even in Rajasthan, one of the semi-arid and desert states, the rainfall recorded in a single day was $773 \mathrm{~mm}$. In Assam alone, the recent flood destroyed 0.2 million hectares of crop area [21].

Bhatta states that, the occurrence of extreme rainfall is increasing while the occurrence of moderate rainfall is decreasing. Moderate rainfall is needed for crop growth. Extreme rainfall, which is above 150 $\mathrm{mm}$ per day has increased by $10 \%$ per decade for the past 50 years. It is estimated that in India the cumulative rainfall was very less in the 2009 monsoon season. The warmest year in India was 2009 since 1901. Due to the failure of the south-west monsoon, the decrease in the area under cultivation was estimated at 5.92 million hectares and the production loss at $10 \%$. Chand and Raju [22] by taking the trend of long term climate data indicate that from 1972-1973 to 2002-2003, except in the north-eastern states, drought occurs frequently once in five years. In states like Rajasthan, Andhra Pradesh, Haryana, Tamil Nadu, Gujarat, Jammu and Kashmir and west Uttar Pradesh drought occurs once in three years. The crop insurance scheme introduced has not made any successful contribution to the ailing farmers.

\section{Farmers' Suicide and their Quitting from Agriculture}

The chronic distress existing in Indian farming has forced nearly five lakh farmers to commit suicide apart from the turning away of 150 million farmers from agriculture. It means that every day nearly 2000 farmers are quitting agriculture [23,24]. Between 1995 and 2011, the number of farmers who committed suicide is 2.71 lakhs [25]. But at the same time the number of farm labourers has increased considerably; by 4.59 million between the 2001 and 2011 Censuses [26]. There is a $6 \%$ decline in the cultivators population and a $35 \%$ increase in the number of agrarian labourers. In Tamil Nadu alone, there was a fall of cultivators by 8.7 lakhs between 2001 and 2011 [27]. The National Crime Record Bureau [4] in its latest report indicates that in 2015 alone, a total of 12,602 persons in the farming sector committed suicide, i.e., one suicide every hour, against 13,754 in 2012. Among the different states, Maharashtra, Madhya Pradesh, Uttar Pradesh and Tamil Nadu account for $50 \%$ of farmer suicides in the country. In 2011, the suicide rate of Indian farmers is $47 \%$ higher than that of the general population. The farmers' suicide rate was 16.3 per lakh farmers against 11.1 for the rest of the population. The rate is $100 \%$ higher in states where there is agrarian crisis. It is reported that a farmer in Andhra Pradesh is three times more likely to commit suicide than anyone else in the country. The same situation exists in Maharashtra also. M.S. Swaminathan report submitted 11 years back indicates that nearly $40 \%$ of the farmers are ready to switch from farm to non-farm activities, but Singh observes that more than $80 \%$ of farmers wish to give up farming.

There are also other reasons for farmers quitting agriculture. Kolappan $[28,29]$ lists out the reasons for continuous decline in the area under cultivation in Tamil Nadu. The reasons are conversion of farm lands into non-farm lands, non-availability of farm labourers, vagaries of monsoon, dwindling water resources, high cost of cultivation, low farm returns, obsolete technologies and imperfect adoption of innovative technologies. But Prabu [30] points out that the main reason for the sharp decline in the area under cultivation is the unbridled real estate business. The income from farms is coming down and even that income is not certain due to vagaries of nature while the price of fertile cultivable land increases as there is high demand for land from realtors and hence, most of cultivable land that has good air and plenty of water is converted into housing plots and is expected that within 10 years, a good part of the fertile land in Tamil Nadu will become housing plots or uncultivated land.

\section{Discussion}

\section{The NDA government and agriculture}

The five programmes announced by the present NDA government to double the farmers' income within five years, i.e., before 2022, have not yet taken off. They are termed as 'the cruellest joke' by many researchers as nothing solid is carried out in that direction. Though out of 149 identified major and medium irrigation projects under Accelerated Irrigation Benefits Programme of Pradhan Mantri Krishi Sinchayee Yojana, 99 were given priority for implementation and out of these 99 projects, 23 were shortlisted for completion by March 31, 2017, no project has been completed so far. The next scheme announced is 
Citation: Kanmony JC (2017) The 50th Year of Green Revolution- Why This Cataclysmic Turn after 1995? Review Pub Administration Manag 5: 224. doi:10.4172/2315-7844.1000224

Page 4 of 4

Pradhan Mantri Fasal Bima Yojana to provide crop insurance to farmers. Under this scheme also farmers have not been benefitted much; though the claim was for Rs.82,354 lakh in 2016-'17 only Rs.20,936 lakh was paid. The third scheme is Soil Health Cards to improve soil health for more production. But as on 21 March 2017 the Ministry has issued just 58.2 million cards against the target of 140 million cards. Price stabilisation fund establishment is the fourth scheme to stabilise the income of farmers. But prices are violently fluctuating. Food inflation is in check at the cost of farmers. Only little efforts are made to start warehouses and so farmers throw away their produce after a bumper harvest due to non-remunerative price. The scheme to set up centres to develop indigenous breeds of cattle called Rashtriya Gokul Mission is the fifth scheme. Under this scheme the government sanctioned Rs. 150 crore in 2014 to set up 15 cattle centres (gokul grams), but not a single centre has been completed or opened so far [31].

\section{Conclusion}

Thus, there are ample chances for the worsening of the farmingrelated problems in the future, if the present situation continues. It is real that the cost of cultivation is escalating, while the prices of their products get stagnated or decline. Farmers are moving away from agriculture, as it is risky and unprofitable. Non-remunerative prices and unfavourable climate changes make the Indian farmers highly indebted. They are not able to repay the loans that they have already borrowed. Lakhs of Indian farmers are committing suicides due to their indebtedness. Hence it is the right time to take suitable measures to protect farmers and farming. Otherwise very soon India will become once again a 'ship-to-mouth economy'.

\section{References}

1. Chengal RP (2017) The ignored sector, Down to Earth, India. p. 34.

2. Kanmony JC (2009) Indian agriculture since the formation of WTO, in Rais Ahmed (ed), WTO and Indian Agriculture, Mittal Publications, New Delhi, India.

3. Jitendra (2017a) Bumper burden, Down to Earth, India. pp. 22-23.

4. Kukreti I, Jitendra (2017) A Nationwide wave, Down to Earth, India. pp. 30-32.

5. Kanmony JC (2017) Is $7.1 \%$ growth of GDP reliable - A view point, Kisan World, India. 7: 24-25.

6. Staff Reporter (2013) Tomato prices crash in Krishnagiri, The Hindu, India. p. 4.

7. Devider S (2004) WTO and Agriculture, Economic and Political Weekly, XXXIX, India. 20: 1997-1998.
8. Richard M (2017) Why farmers now dread a normal monsoon, Down to Earth, India. pp. 16-21.

9. Sainath $\mathrm{P}(2005)$ Farmers" suicides rates soar above the rest, The Hindu, India. p. 1.

10. Sunita N (2017) Mature of taste, Down to Earth, India. p. 3.

11. Jitendra (2017b) The minuscule system of pricing, Down to Earth, India. pp 40-42.

12. Alok $\mathrm{J}$ (2006) The cost of $3^{\circ} \mathrm{C}$ global rise in temperature, The Hindu, India. p. 13.

13. Ajeet S, Jitendra (2017) Import Rs.1,402,680,000,000, Down to Earth, India. pp. 36-39.

14. Nidhi J (2017) Harvest of losses, Down to Earth, India. pp. 26-28.

15. Bhaskar G (2017) Raising the stakes, Down to Earth, India. pp. 44-45.

16. Sathyamoorthy G (2013) Gale flattens banana orchards at a hamlet, The Hindu, India. p. 4.

17. Srinivasan G (2005) Delta Farmers give up on Rice, The Hindu, India. p. 4.

18. Natarajan A, Hedge R, Naidu LGK, Raizada A, Adhikari RN, et al, (2010) Soil and plant nutrient loss during the recent floods in north Karnataka: Implications and ameliorative measures. Current Science 99: 1333-1340.

19. Raju M (2010) Cropping patterns and risk management in the flood plains of Assam, Economic and Political Weekly, XLV 33: 78-81.

20. Gargi $P$ (2009) Climate change threat is very real, Says IFAD Chief, The Hindu, India. p. 18.

21. Subhojit G (2017) Warned, yet unprepared, Down to Earth, India. pp. 14-16.

22. Ramesh C, Raju SS (2009) Dealing with effects of monsoon failures, Economic and Political Weekly, XLIV 41: 39-34.

23. Kedar S (2017) Do we have the answers, Down to Earth, India. pp. 52.

24. Sainath $P$ (2011) Census findings point to decade of rural distress, The Hindu, India. p. 9.

25. Sainath $P$ (2012) Farm suicides rise in Maharastra, The Hindu, India. p. 9.

26. Jain S (2017) An absurd tale, Down to Earth, India. pp. 24-25.

27. Ramakrishnan T (2013) More farmers selling land, turning workers: experts The Hindu, India. p. 4.

28. Kolappan B (2013a) Decline in area of cultivation to cut into farm production, The Hindu, India. p. 7.

29. Kolappan B (2013b) Drop in millets cultivation by $50 \%$, The Hindu, India. p. 4.

30. Prabu MJ (2011) Unbridled real estate business threatens farmer's livelihood', The Hindu, India. p. 16.

31. Deepanwita N (2017) Sick(le) charade, Down to Earth, India. pp. 46-50. 